\title{
Peningkatan Kemampuan Apoteker sebagai Peneliti dalam Upaya Antimicrobial Resistance Awareness
}

\author{
Kartika Citra Dewi Permata Sari*1, Nanda Puspita², Tunggul Adi Purwonugroho3 ${ }^{3}$ Zamharira $^{2}$ \\ Muslim ${ }^{4}$, Ika Mustikaningtias ${ }^{3}$, Fitria Nur Hidayah ${ }^{5}$ \\ ${ }^{1}$ Fakultas Farmasi, Universitas Indonesia \\ 2Politeknik Kesehatan Jakarta 2 \\ ${ }^{3}$ Jurusan Farmasi, Fakultas Ilmu-Ilmu Kesehatan, Universitas Jenderal Soedirman, \\ ${ }^{4}$ Politeknik Kesehatan Bengkulu \\ ${ }^{5}$ Subkomite PRA RSUPN Dr. Cipto Mangunkusumo, Jakarta \\ *e-mail: kartika.citra@farmasi.ui.ac.id
}

\begin{abstract}
Pharmacist practitioners' interest and understanding of antimicrobial research are needed to solve antimicrobial resistance. However, research was more commonly carried out by academics than by practitioners. This community service aimed to increase the interest and understanding of pharmacist practitioners regarding antimicrobial research. It was held as online Focus Group Discussion (FGD) and scientific presentations by experts. Participants voluntary joined this activity by open access registrations. 47 practitioners and 13 academics were arranged into five groups accompanied by an academic facilitator to compose an applicable research outline. The evaluation was conducted using pre-post online questionnaires and observation during discussion. During FGD session, pharmacist practitioners elaborated on antimicrobial problems while academics translated the issues into a research outline. Regardless responses rate questionnaire only $61,67 \%$, all participants interested to follow up their discussion results to be research proposal. In conclusion, FGD between academics and practitioners increase pharmacists' interest and understanding regarding antimicrobial research.
\end{abstract}

Keywords: antimicrobial, FGD, pharmacist, research

\begin{abstract}
Abstrak
Minat dan pemahaman praktisi Apoteker terkait penelitian antimikroba diperlukan untuk berkontribusi terhadap penyelesaian masalah resistensi antimikroba. Akan tetapi, penelitian lebih umum dilakukan oleh para akademisi dibandingkan dengan praktisi. Kegiatan pengabdian masyarakat ini bertujuan meningkatkan minat dan pemahaman praktisi Apoteker terkait penelitian antimikroba. Bentuk kegiatan yang dilakukan adalah Focus Group Discussion (FGD) dan paparan ilmiah oleh narasumber secara daring. Peserta bergabung secara sukarela melalui pendaftaran terbuka. 47 praktisi apoteker dan 13 akademisi dibagi ke dalam lima kelompok dengan fasilitator akademisi untuk menghasilkan kerangka penelitian. Evaluasi dilakukan menggunakan pre-post kuesioner daring dan observasi selama diskusi. Pada sesi FGD, praktisi Apoteker mengelaborasi permasalahan terkait antimikroba sedangkan Para akademisi berkontribusi menerjemahkan permasalahan tersebut menjadi sebuah kerangka penelitian. Walaupun tingkat respon kuesioner hanya 61,67\%, seluruh perserta menyatakan berminat untuk melakukan tindak lanjut hasil diskusi menjadi proposal penelitian. Sebagai kesimpulan, kegiatan FGD antara akademisi dan praktisi terbukti meningkatkan minat dan pemahaman peserta terkait penelitian antimikroba.
\end{abstract}

Kata kunci: antimikroba, apoteker, FGD, penelitian

\section{PENDAHULUAN}

Penggunaan antimikroba yang tidak rasional merupakan permasalahan besar di seluruh dunia. Masalah tersebut berdampak pada lebih cepatnya terjadi resistensi antimikroba (Sweileh, 2021). Resistensi antimikroba merupakan fenomena "silent pandemic" yang dapat mengganggu ketahanan sistem kesehatan seluruh dunia (Mahoney et al., 2021; Sweileh, 2021). Ketidakrasionalan penggunaan antimikroba ditemukan mulai dari tingkat individu, komunitas hingga rumah sakit. Selain itu, faktor pengaruh lain terdiri dari kualitas produk yang tidak baik, lemahnya regulasi, hingga penggunaan yang tidak rasional di hewan serta lingkungan (Ayukekbong et al., 2017). Permasalahan terkait antimikroba telah menyita perhatian seluruh 
dunia hingga memicu kebijakan global seperti "One health approach". Seluruh lini yang terkait dengan penggunaan antimikroba harus berkontribusi dalam mengendalikan laju resistensi antimikroba (Harbarth et al., 2015).

Apoteker sebagai tenaga kesehatan yang bertanggung jawab dalam pengelolaan dan pelayanan terkait obat berperan penting dalam pengendalian penggunaan antimikroba (Sakeena et al., 2018). Selain sebagai praktisi, apoteker juga berperan dalam mempublikasikan data terkait antimikroba melalui penelitian. Di Indonesia, upaya meningkatkan penelitian antimikroba menjadi salah satu strategi utama untuk mengendalikan resistensi (Peraturan Menteri Koordinator Bidang Pembangunan Manusia Dan Kebudayaan Republik Indonesia Nomor 7 Tahun 2021 Tentang Rencana Aksi Nasional Pengendalian Resistensi Antimikroba Tahun 2020-2024, 2021). Data penelitian yang terpublikasi digunakan sebagai dasar bukti penyusunan kebijakan, strategi atau pedoman praktik baik secara lokal, nasional maupun global. Jumlah penelitian dapat mengindikasikan seberapa besar perhatian yang diberikan bagi topik tersebut. Oleh sebab itu, penelitian terkait antimikroba sangat didorong untuk dilakukan banyak pihak termasuk apoteker (Sakeena et al., 2018; Sweileh, 2021).

Secara umum, penelitian lebih sering dilakukan oleh akademisi dibandingkan dengan praktisi. Akan tetapi, hubungan akademisi dan praktisi sebenarnya dapat dikolaborasikan untuk meningkatkan penyusunan penelitian berdasarkan kondisi praktikal yang dihadapi praktisi. Kolaborasi tersebut dapat saling melengkapi kelebihan dan kekurangan dari kedua pihak (Bartunek \& Rynes, 2014). Metode focus group discussion (FGD) merupakan salah satu metode yang paling sering digunakan baik dalam proses pendidikan atau penelitian. FGD umumnya digunakan untuk memperoleh data dari topik tertentu berdasarkan proses diskusi sekelompok orang yang ditentukan. Proses diskusi dalam kelompok umumnya didampingi oleh fasilitator untuk mengarahkan diskusi mencapai hasil yang diharapkan. Dalam proses diskusi dapat dielaborasi data kualitatif dari setiap anggota kelompok. Proses diskusi juga dapat memberikan efek saling mempengaruhi antar anggota kelompok. Output dari FGD umumnya lebih majemuk dikarenakan merupakan hasil kesepakatan seluruh anggota kelompok (Acocella, 2012; O.Nyumba et al., 2018). Selain itu, metode FGD juga efektif digunakan untuk membuat suatu perencanaan (Prahati et al., 2017).

Sejalan dengan strategi RAN pengendalian resistensi antimikroba, peningkatan kesadaran dan pemahaman tentang resistensi antimikroba dapat dilakukan melalui komunikasi, pendidikan dan pelatihan. Penelitian sebelumnya juga menunjukkan bahwa adanya pelatihan mengenai metode penelitian dan penulisan ilmiah menjadi faktor penting yang mendorong peningkatan publikasi dari praktisi farmasi (Morris et al., 2011). Oleh sebab itu, tim pengabdi merancang kegiatan pengabdian masyarakat berupa pelatihan yang bertujuan untuk meningkatkan minat dan pemahaman praktisi apoteker terkait penelitian antimikroba. Menimbang sasaran kegiatan adalah populasi praktisi apoteker dan akademisi maka metode yang digunakan harus sesuai dengan model pembelajaran dewasa. Karakteristik pembelajaran dewasa adalah tingkat urgensi pembelajaran bergantung pada persepsi individu dan tersedianya kesempatan untuk mengutarakan input dari peserta (Aliping \& Parcasio, 2018). Metode FGD dipilih sebagai metode yang umum digunakan dalam pembelajaran dewasa. Selain itu, FGD juga umum digunakan untuk mengakomodasi pendalaman pemahaman dari kelompok tertentu terhadap suatu isu (O.Nyumba et al., 2018). Penerapan metode FGD menjadi kelebihan kegiatan pelatihan ini yaitu mengakomodasi kolaborasi akademisi-praktisi apoteker dalam diskusi mendalam terkait penelitian antimikroba. Selain itu, penentuan hasil diskusi berupa kerangka penelitian diharapkan merangsang level kognitif tingkat tertinggi yaitu kemampuan menciptakan (Goedhart et al., 2019). Pencapaian kegiatan diukur melalui luaran diskusi berupa kerangka penelitian, observasi selama proses diskusi, dan data kuesioner dari peserta. Kegiatan pengabdian masyarakat ini diharapkan dapat berkontribusi terhadap peningkatan minat dan pemahaman praktisi apoteker terkait penelitian antimikroba. Selain itu, kerangka penelitian yang dihasilkan dari diskusi kelompok dapat ditindaklanjuti untuk menjadi proposal penelitian yang siap laksana. 


\section{METODE}

Kegiatan pengabdian masyarakat ini dilakukan secara daring menggunakan Zoom ${ }^{\circledR}$ dengan metode perolehan peserta secara voluntary participative. Sasaran peserta adalah praktisi apoteker dan akademisi farmasi yang berada di seluruh Indonesia. Publikasi kegiatan dilakukan melalui akun media sosial dan broadcast Whatsapp ${ }^{\circledR}$. Metode rekrutmen peserta dilakukan secara convenience sampling dengan kuota sebanyak 80 orang untuk mengefektifkan proses diskusi di setiap grup. Pemberian Satuan Kredit Profesi (SKP), yang diperoleh berdasarkan Surat Keputusan Pengurus Daerah Ikatan Apoteker Indonesia (IAI) DKI Jakarta, digunakan sebagai kompensasi peserta. Evaluasi capaian kegiatan dilakukan secara kuantitatif dan kualitatif menggunakan instrumen kuesioner pre-post dan observasi selama proses diskusi. Data kuantitatif dianalisis secara deskriptif diperoleh dari isian kuesioner meliputi parameter sosiodemografis, persepsi, ide, pengalaman, dan tantangan peserta terkait penelitian antimikroba. Parameter post-assesment terdiri dari minat dan pengetahuan terkait penelitian antimikroba. Data kualitatif diperoleh dari hasil observasi yang dilakukan oleh setiap fasilitator grup dalam proses diskusi.

\section{HASIL DAN PEMBAHASAN}

Tim pengabdi merupakan akademisi bidang farmasi dari berbagai universitas dan praktisi apoteker yang tergabung dalam komunitas Apoteker Peduli AMR (APA). Fokus dari komunitas APA adalah berkontribusi terhadap upaya pengendalian resistensi antimikroba di Indonesia. Berdasarkan data penelitian dan laporan di seluruh dunia, masalah terkait penggunaan antimikroba masih banyak terjadi hingga saat ini (Centers for Disease Prevention and Control, 2020). Pada kondisi pandemi COVID-19, hasil penelitian juga menunjukkan adanya peningkatan swamedikasi antibiotik sebagai dampak simpang siurnya informasi dan kepanikan masyarakat (Zhang et al., 2021). Apoteker berperan penting dalam pengendalian antimikroba sehingga dibutuhkan minat, kesadaran dan pemahaman yang tinggi mengenai upaya yang dapat dilakukan. Salah satu upaya strategis pengendalian antimikroba adalah peningkatan penelitian sesuai dengan ketetapan RAN Pengendalian Antimikroba Tahun 2020 - 2024. Oleh sebab itu, kegiatan pengabdian masyarakat ini dilakukan untuk meningkatkan minat dan pemahaman Apoteker terkait penelitian antimikroba.

Berdasarkan data registrasi, peserta yang mendaftarkan diri untuk mengikuti kegiatan ini sejumlah 60 orang yang terdiri dari 47 orang praktisi (78,33\%) dan 13 orang akademisi $(21,67 \%)$. Praktisi yang mendaftar berasal dari rumah sakit 29 orang (48,33\%), apotek 9 orang (15\%), klinik 4 orang $(6,67 \%)$, puskesmas 3 orang (5\%) dan sisanya berasal dari distributor serta regulator masing-masing 1 orang. Domisili peserta berasal dari 15 provinsi di Indonesia dengan mayoritas berada di Jawa Timur (25\%). Keberagaman tersebut merupakan salah satu dampak kelebihan kegiatan yang dilakukan secara daring. Pelaksanaan kegiatan secara daring meningkatkan partisipasi peserta dari berbagai tempat dibandingkan kegiatan luring (Xie et al., 2020). Walaupun kuota peserta tidak mencapai maksimal namun respon yang diperoleh sebesar 75\% dapat dikategorikan cukup tinggi. Tingginya angka peserta dari praktisi menunjukkan tingginya minat dari praktisi apoteker mengikuti kegiatan terkait penelitian antimikroba. Data sosiodemografis dan minat awal peserta pada penelitian antimikroba ditampilkan pada Tabel 1.

Hingga saat ini, regulasi mengenai evaluasi dan penggunaan antimikroba di Indonesia lebih banyak tersedia untuk tingkat rumah sakit dibandingkan dengan komunitas (Kementerian Kesehatan RI, 2020; World Health Organization, 2019). Oleh sebab itu, dapat dipahami jika mayoritas peserta praktisi yang mendaftar berasal dari rumah sakit. Hal tersebut kemungkinan disebabkan praktisi apoteker di rumah sakit lebih familiar dengan penelitian antimikroba sehingga berminat mengikuti kegiatan FGD. Data publikasi sebelumnya juga menunjukkan bahwa praktisi farmasi di rumah sakit yang juga merupakan institusi akademis dilaporkan memiliki publikasi penelitian yang lebih banyak dibanding praktisi farmasi di tempat praktik biasa (Badowski et al., 2017). 
Tabel 1. Data sosiodemografis peserta

\begin{tabular}{cc}
\hline Parameter & Jumlah (\%) \\
\hline Jenis kelamin & $10(16,67 \%)$ \\
Laki-laki & $50(83,33 \%)$ \\
Perempuan & $10(16,67 \%)$ \\
Asal provinsi & $9(15 \%)$ \\
Banten & $10(16,67 \%)$ \\
DKI Jakarta & $15(25 \%)$ \\
Jawa Barat & $16(26,67)$ \\
Jawa Timur & \\
lainnya & $47(78,33 \%)$ \\
Kategori peserta & $13(21,67 \%)$ \\
Praktisi & \\
Akademisi & $29(48,33 \%)$ \\
Asal instansi & $9(15 \%)$ \\
Rumah sakit & $4(6,67 \%)$ \\
Apotek & $3(5 \%)$ \\
Klinik & $1(1,67 \%)$ \\
Puskesmas & $1(1,67 \%)$ \\
Distributor & \\
Regulator &
\end{tabular}

Dua hari sebelum kegiatan dimulai, peserta diberikan formulir online untuk perolehan data self-assessment. Formulir tersebut berisi 10 pertanyaan yang meliputi 2 pertanyaan data diri (nama dan instansi) dan 8 pertanyaan terkait penelitian antimikroba. Pertanyaan terkait penelitian antimikroba terdiri dari pertanyaan dengan pilihan jawaban skala Likert dan isian free text masing-masing 4 buah. Response rate dari formulir self-assessment tidak sesuai dengan harapan tim pengabdi. Tim pengabdi sudah mengupayakan untuk mengingatkan kembali peserta hingga pelaksanaan FGD namun response rate di akhir kegiatan hanya sebesar 51,33\% (31 orang) yang terdiri dari 24 orang praktisi dan 7 orang akademisi. Kedua kelompok peserta memiliki response rate sebesar masing-masing 51,06\% dan 53,85\%. Secara umum dapat dinyatakan bahwa kedua kelompok peserta memberikan tingkat respon yang sama saat diminta mengisi formulir self-assessment. Saat melakukan diskusi di dalam kelompok, didapatkan berbagai alasan yang dikemukakan oleh peserta sehingga tidak mengisi kuesioner. Alasan umum yang diutarakan adalah peserta tidak sempat mengisi. Namun, secara garis besar hasil diskusi di kelompok menunjukkan hasil yang serupa dengan olahan data isian yang ada. Hasil dan alasan peserta tidak mengisi formulir self-assessment ditampilkan pada Tabel 2.

Tabel 2. Hasil data self-assessment

\begin{tabular}{cccc}
\hline Parameter & \multicolumn{3}{c}{ Jumlah (\%) } \\
\cline { 2 - 4 } & Total & Praktisi & Akademisi \\
\hline Respon & $31(51,33 \%)$ & $24(51,06 \%)^{*}$ & $7(53,85 \%)^{*}$ \\
Mengisi & $29(48,67 \%)$ & $23(48,94 \%)^{*}$ & $6(46,15 \%)^{*}$ \\
Tidak mengisi & & & \\
Minat penelitian & $29(77,42 \%)^{* * *}$ & $22(91,67 \%)^{* *}$ & $7(100 \%)^{* *}$ \\
Ya & $2(22,58 \%)^{* * *}$ & $2(8,3 \%)^{* *}$ & - \\
Tidak & & & \\
Pengalaman melakukan penelitian & & & \\
selama bekerja & $20(64,52 \%)$ & $13(54,17 \%)^{* *}$ & $7(100 \%)^{* *}$ \\
Ya & &
\end{tabular}




\begin{tabular}{|c|c|c|c|}
\hline \multirow[t]{2}{*}{ Parameter } & \multicolumn{3}{|c|}{ Jumlah (\%) } \\
\hline & Total & Praktisi & Akademisi \\
\hline Tidak & $11(35,48 \%)$ & $11(45,83 \%)^{* *}$ & - \\
\hline \multicolumn{4}{|l|}{$\begin{array}{l}\text { Persepsi bahwa praktisi apoteker } \\
\text { perlu memahami prosedur penelitian }\end{array}$} \\
\hline Sangat tidak setuju & $1(3,23 \%)^{* * *}$ & $1(4,17 \%)^{* *}$ & - \\
\hline Cukup setuju & $1(3,23 \%)^{* * *}$ & $1(4,17 \%)^{* *}$ & - \\
\hline Setuju & $6(19,35 \%)^{* * *}$ & $5(20,83 \%)^{* *}$ & $1(14,29 \%)^{* *}$ \\
\hline Sangat setuju & $23(74,19 \%)^{* * *}$ & $17(70,83 \%)^{* *}$ & $6(85,71 \%)^{* *}$ \\
\hline Median [min-max] & $5[1-5]$ & $5[1-5]$ & $5[4-5]$ \\
\hline \multicolumn{4}{|l|}{$\begin{array}{l}\text { Persepsi bahwa praktisi apoteker } \\
\text { perlu melakukan penelitian }\end{array}$} \\
\hline Tidak setuju & $2(6,45 \%)^{* * *}$ & $2(8,33 \%)^{* *}$ & - \\
\hline Cukup setuju & $2(6,45 \%)^{* * *}$ & $1(4,17 \%)^{* *}$ & $1(14,29 \%)^{* *}$ \\
\hline Setuju & $9(29,03 \%)^{* * *}$ & $8(33,33 \%)^{* *}$ & $1(14,29 \%)^{* *}$ \\
\hline Sangat setuju & $18(58,07 \%)^{* * *}$ & $13(54,17)^{* *}$ & $5(71,42 \%)^{* *}$ \\
\hline Median [min-max] & $5[2-5]$ & $5[2-5]$ & $5[3-5]$ \\
\hline $\begin{array}{c}\text { Alasan tidak mengisi kuesioner self- } \\
\text { assessment }\end{array}$ & \multicolumn{3}{|c|}{$\begin{array}{c}\text { "belum sempat mengisi di sela-sela kerja kemarin" } \\
\text { "tidak sadar ada permintaan isian self- } \\
\text { assessment" } \\
\text { "ingin menjawab saat diskusi saja secara } \\
\text { langsung" }\end{array}$} \\
\hline
\end{tabular}

Keterangan: *persentase dihitung berdasarkan jumlah total peserta per kategori; ** persentase dihitung berdasarkan total respon kuesioner per kategori peserta; ${ }^{* * *}$ persentase dihitung berdasarkan total respon kuesioner

Berdasarkan isian data self-assessment diperoleh bahwa hampir seluruh peserta $(77,42 \%)$ memiliki minat terkait penelitian antimikroba. Seluruh praktisi apoteker rumah sakit yang mengisi kuesioner menyatakan berminat terhadap penelitian antimikroba. Terdapat 2 orang peserta yang berasal dari klinik dan apotek yang menyatakan tidak memiliki minat terhadap penelitian antimikroba. Seluruh peserta akademisi yang mengisi self-assessment menyatakan memiliki minat terkait penelitian antimikroba. Walaupun minat terkait penelitian antimikroba tergolong tinggi, namun hanya $54,17 \%$ praktisi yang pernah melakukan penelitian selama bekerja. Fenomena ini juga selaras dengan hasil penelitian sebelumnya yang menyatakan hanya 46,7\% praktisi farmasi di Amerika yang melakukan publikasi artikel (Badowski et al., 2017). Kelompok praktisi yang menyatakan pernah melakukan penelitian berasal dari rumah sakit ( 9 orang); apotek (3 orang), dan puskesmas (1 orang). 75\% praktisi apoteker di klinik menyatakan tidak pernah melakukan penelitian. Di sisi lain, seluruh peserta akademisi menyatakan pernah melakukan penelitian. Data tersebut sejalan dengan penelitian sebelumnya yang mengelaborasi hubungan antara akademisi dan praktisi. Akademisi lebih banyak melakukan penelitian sehingga berpikir lebih sistematis dan teoritis dibandingkan dengan praktisi. Bagi praktisi sisi praktikal berdasarkan pengalaman yang ada lebih berpengaruh terhadap cara berpikirnya (Bartunek \& Rynes, 2014; De Pelecijn \& Feys, 2021; McCabe et al., 2021). Selain itu, tingginya minat dan pengalaman praktisi rumah sakit terkait penelitian juga dapat mengindikasikan bahwa selama ini kolaborasi penelitian akademisi-praktisi mayoritas terjadi di tingkat rumah sakit dibandingkan komunitas.

Secara umum mayoritas peserta sangat setuju praktisi apoteker perlu memahami prosedur penelitian dan melakukan penelitian terkait antimikroba. Walaupun secara statistik tidak diperoleh perbedaan signifikan, namun terdapat perbedaan persepsi dari peserta akademisi dan praktisi terkait hal tersebut. Hasil selanjutnya adalah masih didapatkan adanya persepsi peserta praktisi yang menyatakan tidak setuju jika praktisi perlu melakukan penelitian. Hal ini kontradiktif dengan persepsi akademisi yang setuju bahwa praktisi perlu melakukan penelitian. 
Hasil tersebut mengindikasikan masih adanya perbedaan persepsi terkait urgensi penelitian bagi kedua kelompok peserta. Akademisi memiliki persepsi bahwa praktisi perlu terlibat melakukan penelitian disebabkan adanya kebutuhan kontribusi ide masalah dan solusi berdasarkan pengalaman praktisi (Babar et al., 2018). Namun praktisi dapat berpikir bahwa melakukan pekerjaan hariannya lebih penting dibandingkan melakukan penelitian yang berkutat dengan data dan teori. Perbedaan persepsi tersebut dapat menghambat adanya kolaborasi akademisi dan praktisi untuk melakukan penelitian (Bartunek \& Rynes, 2014; De Pelecijn \& Feys, 2021). Adanya FGD diharapkan dapat menjadi wahana diskusi akademisi-praktisi untuk mencapai kesepakatan persepsi terkait penelitian sesuai kebutuhan masing-masing kelompok.

Pada kuesioner self-assessment, peserta juga diminta memberikan isian ide, peluang dan hambatan terkait penelitian antimikroba berdasarkan pengalamannya. Berdasarkan jawaban yang diberikan, dapat dikelompokkan beberapa topik yang sejenis sebagaimana ditampilkan pada Tabel 3. Resistensi dan rasionalitas penggunaan antibiotik menjadi ide mayoritas peserta sebagai topik penelitian. Hal ini sejalan dengan fokus utama permasalahan antimikroba di seluruh dunia (Harbarth et al., 2015; Sweileh, 2021; Yam et al., 2019). Mayoritas peserta juga menyampaikan adanya keterbatasan waktu, biaya, dan data yang tidak lengkap menjadi penghambat untuk melaksanakan penelitian. Hal tersebut sejalan dengan hasil penelitian sebelumnya bahwa hambatan utama yang dilaporkan adalah kurangnya waktu, beban pekerjaan harian, kurangnya pendanaan dan dukungan, serta kurangnya pengetahuan tentang penelitian. Mayoritas praktisi farmasi melakukan publikasi penelitian hanya pada masa pendidikan (Awaisu \& Alsalimy, 2015; Morris et al., 2011). Hasil self-assesment juga mendapatkan faktor lain seperti "kerja sama dalam membangun komitmen bersama disana, TS yang lain peduli, ada yg tidak peduli sehingga tujuan agak sulit dicapai" sebagai hambatan pelaksanaan penelitian. Hal ini mengindikasikan bahwa untuk melaksanakan penelitian diperlukan kolaborasi tim. Oleh sebab itu, umumnya penelitian lebih sering ditemukan sebagai bentuk kolaborasi antara akademisi-praktisi dibandingkan dengan praktisi-praktisi (De Pelecijn \& Feys, 2021). Adanya dukungan manajemen dan peluang kerja sama dari berbagai pihak dinyatakan oleh peserta sebagai faktor peluang pelaksanaan penelitian. Persepsi tersebut sejalan dengan hasil penelitian yang menyebutkan bahwa tersedianya mentor, kolaborasi tim, dukungan instansi dan kesempatan hibah pendanaaan dapat mendorong minat para praktisi untuk melakukan penelitian di lingkungan kerjanya (Awaisu \& Alsalimy, 2015; Badowski et al., 2017; Morris et al., 2011). Selain itu ada juga peserta praktisi yang menyampaikan ".... pekerjaan utama yang urgent dan prioritas"; "penelitian dilaksanakan sambil melakukan tugas harian, jadi kurang fokus" mengindikasikan bahwa memang pekerjaan harian utama praktisi dianggap sebagai hambatan untuk melakukan penelitian. Ditambah adanya pernyataan dari peserta akademisi terkait sulitnya kerja sama penelitian dengan tempat praktik berdasarkan pernyataan "pengambilan data di pelayanan kesehatan sulit"; "....beberapa instansi yang tertutup"; "tempat penelitian yang susah dijangkau...". Hal tersebut membuktikan paradoks persepsi dari kelompok praktisi dan akademisi. Fokus dari praktisi adalah mengerjakan tugas harian yang lebih utama dibanding melakukan penelitian sehingga seringkali akademisi sulit mengakses tempat pelayanan kesehatan sebagai lokasi penelitian (Bartunek \& Rynes, 2014).

Tabel 3. Data kualitatif isian self-assessment

\begin{tabular}{ccl}
\hline Parameter & & \multicolumn{1}{c}{ Topik jawaban } \\
\hline Ide & $\bullet$ & Resistensi dan penggunaan antimikroba yang tidak rasional \\
penelitian & $\bullet$ & Evaluasi penggunaan antibiotik pada populasi khusus (pediatri, pasien \\
& & penyakit jantung, pasien operasi, pasien COVID) \\
& $\bullet$ & Audit kualitatif dan kuantitatif penggunaan antibiotik \\
& - & Tingkat pengetahuan dan kepatuhan masyarakat terkait penggunaan \\
& & antimikroba \\
Hambatan & $\bullet$ & Drug discovery \\
penelitian & $\bullet$ & Terbatasnya waktu, biaya dan tenaga \\
\hline
\end{tabular}




\begin{tabular}{ccl}
\hline & $\bullet$ & Pekerjaan utama lebih prioritas \\
& - Sulitnya akses ke fasilitas pelayanan kesehatan (akibat keterbatasan \\
& & izin instansi, pandemi COVID-19) \\
& - & Kesulitan sumber data penelitian (data yang kurang lengkap, \\
Peluang & - Tingonden yang kurang antusias, perilaku responden yang tidak jujur) \\
penelitian & $\bullet$ Adanya dukungan manajemen dan tim \\
& - Adanya kerja sama dari berbagai pihak, hibah dari instansi lain \\
\hline
\end{tabular}

Hal yang menarik adalah tingginya resistensi antimikroba dan penggunaan yang tidak rasional dinyatakan oleh mayoritas peserta sebagai peluang pelaksanaan penelitian. Pola tersebut menunjukkan bahwa mayoritas peserta menganggap masalah adalah peluang penelitian. Sesuai dengan fenomena tersebut, pembelajaran atau penelitian yang berfokus pada masalah lebih dapat menginduksi produksi ide (Drăghicescu et al., 2014).

Keseragaman juga diperoleh dari data harapan peserta mengikuti kegiatan FGD ini yaitu meningkatkan pemahaman mengenai metode penelitian, menjalin kerja sama penelitian dan menjadikan pengetahuan terkait penelitian dapat menunjang pelaksanaan praktik di tempat kerja. Harapan yang disampaikan oleh peserta sejalan dengan tujuan kegiatan yang dirumuskan oleh tim pengabdi. Dalam rangka meningkatkan pemahaman peserta, kegiatan dirancang memiliki sesi paparan ilmiah dari narasumber. Selanjutnya sesi FGD dan presentasi ditujukan untuk menjalin kerja sama antar peserta serta meningkatkan pemahaman peserta untuk aplikasi di tempat kerja masing-masing.

Paparan ilmiah dari narasumber ahli membahas mengenai dua hal yaitu pelaksanaan Antimicrobial Stewardship (AMS) dan metodologi penelitian di bidang farmasi praktis. Narasumber ahli yang pertama merupakan dokter praktisi dan akademisi. Narasumber memiliki pengalaman menjadi ketua tim pelaksana Program Pengendalian Resistensi Antimikroba (PPRA) selama 11 tahun (periode tahun 2009-2020). Pada saat paparannya, narasumber juga menyampaikan peran apoteker dalam program AMS. Narasumber menekankan bahwa dalam melaksanakan perannya, apoteker dapat menggunakan data yang diperoleh sebagai penelitian. Hal tersebut sesuai dengan fakta yang diperoleh yaitu penelitian yang terpublikasi dapat mengubah strategi, kebijakan bahkan praktik profesi (Broom et al., 2015; Reynolds \& Rupp, 2017). Pada saat sesi tanya jawab, diperoleh bahwa banyak praktisi mengkonsultasikan permasalahan yang sering ditemukan di tempat praktiknya. Pertanyaan mengenai pelaksanaan metode evaluasi penggunaan obat antibiotik juga didiskusikan dapat menjadi ide penelitian yang bermanfaat bagi tempat praktik apoteker. Dokumentasi kegiatan saat sesi paparan ilmiah ditampilkan pada Gambar 1.

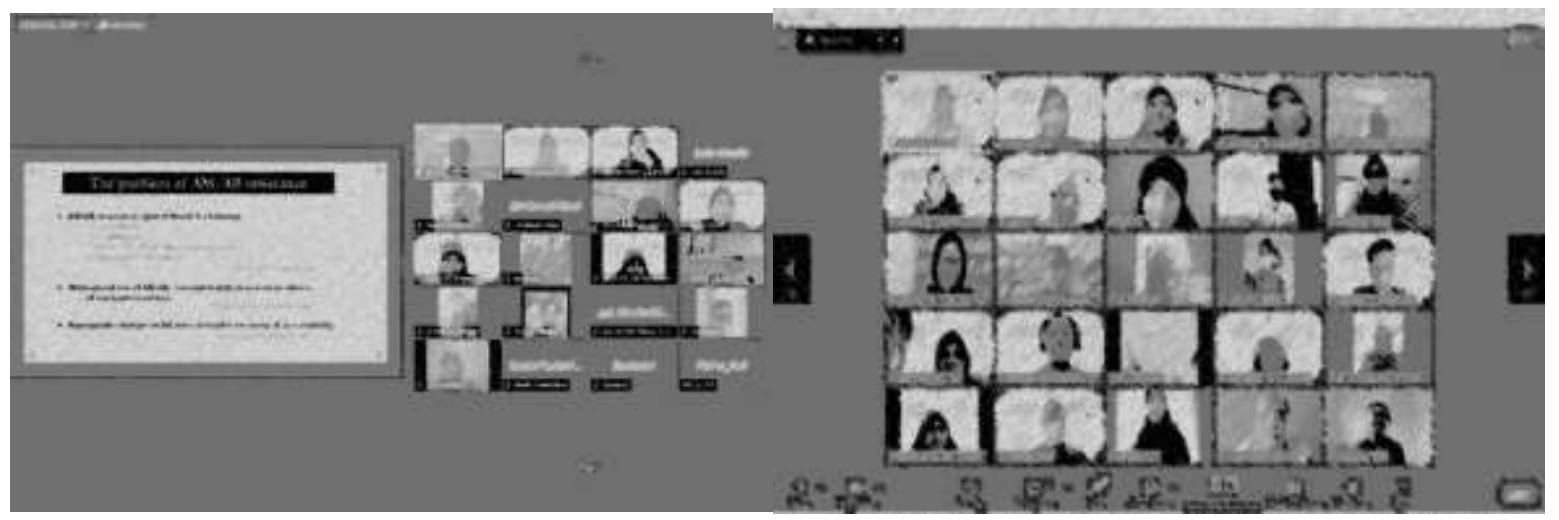

Gambar 1. Dokumentasi kegiatan paparan ilmiah oleh narasumber (gambar asli terlampir, dikarenakan ada identitas penulis) 
Sesi ilmiah kedua dilanjutkan dengan paparan dari narasumber apoteker akademisi. Paparan berisi materi jenis-jenis metodologi penelitian. Narasumber juga memberikan contohcontoh publikasi terkait penelitian antimikroba dengan berbagai metode penelitian. Materi tersebut diharapkan dapat meningkatkan pengetahuan peserta mengenai metode penelitian dan bagaimana menerapkannya. Topik metode penelitian dipilih sebagai materi sesuai dengan hasil penelitian yang menyatakan bahwa salah satu hambatan praktisi melakukan penelitian adalah kurangnya pemahaman terkait metode riset (Awaisu \& Alsalimy, 2015). Pada sesi kedua ini didapati respon pertanyaan mayoritas berasal dari peserta akademisi. Hal tersebut kemungkinan dikarenakan peserta akademisi lebih familiar dengan materi yang ada. Selain itu, adanya keterbatasan waktu juga dapat berpengaruh terhadap minimnya respon dari peserta praktisi pada sesi kedua.

Setelah paparan ilmiah, peserta diarahkan ke dalam breakout room untuk sesi FGD sesuai pembagian yang disusun oleh tim pengabdi. Anggota kelompok diatur sedemikian rupa sehingga setiap kelompok terdiri dari peserta akademisi dan praktisi. Sesi FGD dilakukan selama 90 menit dengan fasilitator sebanyak 1 orang/kelompok. Secara umum, FGD di tiap kelompok diawali dengan perkenalan anggota kelompok dan pemilihan ketua kelompok. Topik yang dieksplorasi dari diskusi kelompok adalah pengalaman anggota terkait penelitian, serta hambatan dan peluang untuk melakukan penelitian di tempat praktek praktisi. Sesi diskusi kemudian menentukan satu tema penelitian yang akan dipresentasikan dalam kelompok besar secara bersama.

\section{A. FGD Kelompok 1}

Anggota kelompok ini terdiri dari apoteker yang berpraktik di apotek, rumah sakit, akademisi, dan apoteker yang bekerja sebagai regulator. Setelah melakukan brainstorming mengenai tema penelitian yang akan diangkat, seluruh peserta menyepakati membuat rancangan penelitian untuk mengevaluasi pengetahuan dan persepsi masyarakat mengenai antibiotik dan bahaya resistensi antibiotik. Penelitian ini berlokasi di komunitas dan menggunakan kuesioner sebagai alat ukurnya. Diharapkan hasil penelitian dapat menjadi acuan untuk membuat intervensi dalam peningkatan kepedulian masyarakat terkait penggunaan antibiotik yang tepat dan resistensi antibiotik.

\section{B. FGD Kelompok 2}

Diskusi kelompok 2 diawali dengan penggalian permasalahan yang terjadi di rumah sakit dan memungkinkan untuk diteliti. Terdapat dua tema besar yang diperoleh yaitu penentuan kebijakan terkait pengelolaan antibiotik dan studi penggunaan antibiotik. Kedua isu ini merupakan isu penting di fasilitas pelayanan kefarmasian. Penentuan kebijakan dalam pengelolaan antibiotik perlu dukungan dari berbagai pihak sehingga riset mengenai topik tersebut perlu diangkat. Namun, isu mengenai kebijakan melibatkan berbagai pihak dan dapat menjadi isu sensitif, sehingga tidak semua praktisi dapat menerapkan riset dengan tema tersebut. Studi penggunaan antibiotik sangat diperlukan datanya untuk berbagai hal termasuk dalam kegiatan pencegahan resistensi antibiotik (Bassetti et al., 2019; Van Katwyk et al., 2020) . Tema ini dapat diterapkan oleh semua praktisi di rumah sakit. Oleh sebab itu, kelompok 2 memutuskan untuk merancang studi penggunaan antibiotik menggunakan teknik Defined Daily Dose (DDD). Desain penelitian yang dilakukan adalah obervasional retrospektif yang akan dilaksanakan di setiap bangsal di rumah sakit. Tujuan penelitian adalah untuk menentukan pola penggunaan antibiotik di setiap rumah sakit. Data yang diperoleh dapat digunakan untuk menentukan ketepatan penggunaan 1447andemic1447c sehingga akan dapat ditentukan gambaran penggunaan 1447 andemic1447c di rumah sakit.

\section{FGD Kelompok 3}

Peserta FGD pada kelompok ini terdiri dari akademisi dan sejumlah praktisi baik dari apotek maupun rumah sakit. Pada saat sesi perkenalan, terdapat seorang praktisi puskesmas yang menceritakan pengalamannya terlibat dalam tim penelitian di rumah sakit tempat bekerjanya dahulu. Pengalaman tersebut yang mendorongnya mengikuti kegiatan FGD untuk 
memotivasi diri melaksanakan penelitian di tempat kerja yang baru yaitu puskesmas. Namun, terdapat kendala utama untuk meneliti yaitu kurangnya personel farmasi di puskesmas.

Sementara itu, diskusi mengenai tema penelitian menghasilkan sejumlah ide, salah satu yang dipilih yaitu mengeksplorasi faktor-faktor yang berhubungan dengan penggunaan 1448andemic1448c di masa 1448andemic COVID-19. Isu mengenai penggunaan 1448andemic1448c tanpa resep masih menjadi masalah kefarmasian yang belum terselesaikan hingga saat ini. Gelombang kedua kasus COVID-19 yang terjadi di bulan Juli 2021 juga berimplikasi pada meningkatnya pembelian 1448andemic1448c tanpa resep. Pada saat diskusi berlangsung, terdapat fenomena menarik mengenai bagaimana memilih metode penelitian yang tepat sesuai tema penelitian yang disepakati. Peserta praktisi kurang memahami tentang pengambilan data secara retrospektif. Sebelumnya, penelitian dianggap hanya dapat dilakukan dengan melakukan intervensi terhadap responden dan mengamati outcome secara prospektif. Melalui diskusi kelompok, diperoleh pemahaman baru oleh peserta praktisi mengenai metode penelitian retrospektif. Dalam kelompok ini, dinamika kelompok masih dirasa kurang karena 1448andemic besar peserta mematikan kamera dan berdiskusi hanya melalui fitur chat dalam zoom.

\section{FGD Kelompok 4}

Sesi FGD diawali dengan perkenalan masing-masing peserta berkaitan dengan latar belakang pekerjaan dan minat penelitian. Dari hasil perkenalan diketahui bahwa latar belakang pekerjaan peserta berasal dari praktisi klinis rumah sakit dan akademisi. Setelah sesi perkenalan, dilanjutkan dengan penyampaian ide-ide penelitian yang akan diajukan sebagai judul penelitian kelompok. Dikarenakan salah satu peserta kelompok bekerja di Rumah Sakit rujukan pemerintah untuk penanganan pasien Covid-19, maka para peserta setuju akan mengajukan judul penelitian yang berkaitan dengan penanganan pasien Covid-19 khususnya pada pasien lansia. Draft penelitian disusun secara bersama-sama dengan diketuai oleh satu orang peserta.

\section{E. FGD Kelompok 5}

Kelompok 5 terdiri dari praktisi apoteker di komunitas dan akademisi. Peserta di kelompok 5 berasal dari berbagai daerah yang berbeda-beda meliputi Jabodetabek, Yogyakarta, dan Malang. Walaupun dari berbagai daerah ternyata pada sesi diskusi, praktisi apoteker komunitas tersebut mengemukakan permasalahan yang 1448andemic sama yaitu penggunaan antimikroba yang tidak rasional di apotek. Masalah tersebut bukan isu yang baru pada penelitian antimikroba namun praktisi menyatakan bahwa hal tersebut masih belum dapat diatasi hingga saat ini khususnya di Indonesia. Pada proses diskusi juga dibahas mengenai penelitian-penelitian yang sudah ada sebelumnya terkait isu tersebut. Penggunaan antimikroba yang tidak rasional pada masa 1448andemic COVID-19 juga dibahas sebagai potret permasalahan terkini. Diskusi mengarah pada pentingnya memahami persepsi dan sikap apoteker di apotek mengenai pelayanan obat antimikroba.

Pada saat menyusun kerangka penelitian, didapati fenomena bahwa praktisi apoteker lebih menyerahkan prosesnya kepada peserta akademisi. "Saya bisa bilang masalahnya ini, tapi ga tau gimana cara bikinnya jadi penelitian..." adalah salah satu pernyataan peserta praktisi saat mulai menyusun kerangka penelitian. Fasilitator mendorong peserta akademisi untuk memimpin proses penyusunan kerangka penelitian namun disertai penjelasan mengapa metode maupun prosedur penelitian tersebut dipilih. Diharapkan perlakuan tersebut dapat meningkatkan pemahaman peserta praktisi. Adanya peserta praktisi yang menyatakan "Oh bisa ya, penelitian itu hasilnya bukan angka-angka, kualitatif begitu" membuktikan bahwa metode penelitian kualitatif merupakan hal yang baru diketahuinya. Pada akhir sesi diskusi, kelompok 5 dapat menyelesaikan luaran berupa kerangka penelitian untuk dipresentasikan di hadapan narasumber. 
Setelah proses FGD setiap kelompok selesai, seluruh peserta diminta kembali ke ruang utama untuk mempresentasikan hasil diskusi kelompok. Narasumber kedua yang merupakan akademisi diminta untuk memberikan umpan balik terhadap hasil diskusi kelompok. Pada sesi presentasi tersebut didapatkan bahwa seluruh kelompok dapat menghasilkan tema penelitian yang berbeda-beda. Ruang lingkup penelitian juga sangat beragam baik dari lokasi penelitian maupun metode penelitian yang digunakan. Narasumber menilai bahwa proses diskusi tiap kelompok sudah sangat baik walaupun hanya tiga kelompok yang dapat menghasilkan kerangka penelitian secara lengkap. Waktu diskusi yang hanya 90 menit dianggap wajar bila tidak dapat menyelesaikan kerangka penelitian secara lengkap. Dokumentasi sesi umpan balik ditampilkan pada Gambar 2.

Di akhir sesi, beberapa perwakilan peserta diminta memberikan umpan balik secara lisan mengenai kegiatan yang dilakukan. Perwakilan peserta praktisi menyatakan bahwa "...kegiatan seperti ini harus sering dilakukan karena kita yang praktisi jadi banyak tahu tentang penelitian....". Peserta akademisi menambahkan "...acara ini membuka peluang kolaborasi lebih luas lagi, kami jadi banyak dapat input ide masalah dari teman-teman praktisi...". Harapan peserta kerangka ide penelitian yang dihasilkan dari FGD dapat ditindaklanjuti menjadi penelitian.

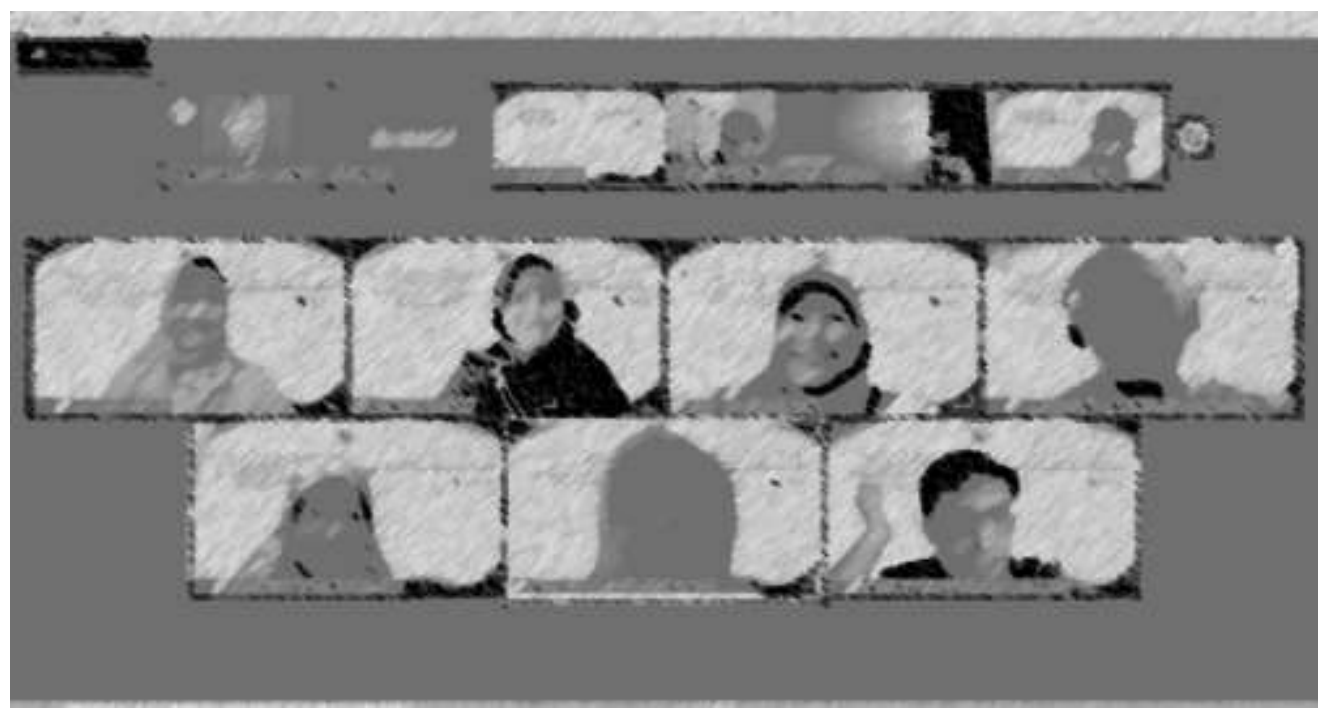

Gambar 2. Dokumentasi sesi umpan balik oleh narasumber dan fasilitator (gambar asli terlampir, dikarenakan ada identitas penulis)

Pada akhir kegiatan, terdapat kuesioner post-assessment yang bertujuan untuk mengkaji persepsi manfaat kegiatan dan perubahan minat peserta terhadap penelitian. Response rate dari peserta hanya 61,67\% (37 orang). Berdasarkan respon yang diperoleh, mayoritas peserta (35 orang) menyetujui bahwa kegiatan workshop dapat meningkatkan minat meneliti, hanya dua orang yang menyatakan ragu-ragu atau tidak setuju terhadap adanya peningkatan pemahaman dan minat setelah mengikuti kegiatan ini. Akan tetapi, keduanya menyatakan berminat untuk menindaklanjuti kerangka penelitian hasil diskusi kelompoknya dan bersedia bila diajak berkolaborasi. Kedua peserta tersebut berasal masing-masing dari klinik dan rumah sakit. Terdapat sejumlah kemungkinan tentang respon negatif peserta tersebut. Pertama, kurangnya durasi kegiatan dan dinamika kelompok mungkin menjadi penyebab perbedaan persepsi dari kedua peserta tersebut. Kedua, peserta yang berasal dari rumah sakit memiliki gelar magister yang memiliki pengalaman dan pengetahuan awal tentang penelitian yang memadai sehingga kegiatan ini dirasa tidak menambah secara signifikan pemahamannya tentang cara meneliti. Ketiga, adanya sikap pragmatis akan permasalahan penggunaan antibiotik tanpa resep di kalangan masyarakat saat ini sehingga menurunkan minat meneliti. 
Berdasarkan output yang dihasilkan dari kegiatan dan data post-assessment, kegiatan FGD praktisi-akademisi ini dianggap mampu untuk meningkatkan minat dan pemahaman praktisi Apoteker mengenai penelitian antimikroba. Hal tersebut sejalan dengan penelitian sebelumnya yang menunjukkan bahwa adanya kolaborasi praktisi dengan peneliti atau akademisi dapat meningkatkan minat dan pemahaman mengenai penelitian (Awaisu \& Alsalimy, 2015; Badowski et al., 2017; Morris et al., 2011). Peningkatan yang dapat dilakukan untuk kegiatan sejenis ke depannya adalah adanya kontrak komitmen yang harus dipenuhi oleh peserta sebelum kegiatan dimulai, adanya pendalaman materi mengenai metode penelitian, diskusi kelompok dibuat dalam beberapa kali sesi, dan kegiatan dilakukan dengan periode waktu yang lebih panjang. Akan lebih baik bila kegiatan yang dilakukan difasilitasi untuk mendapatkan hibah penelitian dari kolaborasi akademisi sehingga proposal yang dihasilkan dapat ditindaklanjuti.

\section{KESIMPULAN}

- Minat praktisi apoteker terkait penelitian antimikroba sudah cukup tinggi walaupun hanya sebagian yang memiliki pengalaman melakukan penelitian selama bekerja.

- Mayoritas praktisi apoteker menyatakan hambatan melakukan penelitian adalah waktu dan sumber daya yang terbatas.

- Pemahaman praktisi apoteker terkait prosedur dan metode penelitian masih perlu ditingkatkan sehingga dapat mengubah persepsi mengenai kesulitan melaksanakan penelitian di tempat praktik

- Dalam proses diskusi, praktisi apoteker terbukti memberikan kontribusi berupa ide permasalahan antimikroba yang terjadi di fasilitas kesehatan sedangkan akademisi mengarahkan metode dan kerangka penelitian sesuai kaidah ilmiah.

- Kolaborasi praktisi dan akademisi apoteker dalam FGD terbukti meningkatkan pemahaman praktisi mengenai prosedur dan metode penelitian.

- Kolaborasi praktisi dan akademisi apoteker dalam FGD terbukti dapat menghasilkan kerangka penelitian yang berkontribusi pada masalah antimikroba di fasilitas pelayanan kesehatan atau masyarakat.

\section{UCAPAN TERIMA KASIH}

Penulis mengucapkan terima kasih kepada Prof. Dr. dr. Taralan, Sp.A(K) dan Anna Wahyuni Widayanti, M.P.H., Apt., Ph.D selaku narasumber dalam kegiatan pengabdian masyarakat ini. Terima kasih kami sampaikan juga kepada Pengurus Daerah Ikatan Apoteker Indonesia DKI Jakarta yang telah mendukung kegiatan ini dengan pemberian nilai SKP.

\section{DAFTAR PUSTAKA}

Acocella, I. (2012). The focus groups in social research: Advantages and disadvantages. Quality and Quantity, 46(4), 1125-1136. https://doi.org/10.1007/s11135-011-9600-4

Aliping, J. B., \& Parcasio, I. G. (2018). Training Design Facilitation Framework for Adult Education: An Application of Andragogy. Mountain Journal of Science and Interdisciplinary Research, 78(2), 95-113.

Awaisu, A., \& Alsalimy, N. (2015). Pharmacists' involvement in and attitudes toward pharmacy practice research: A systematic review of the literature. Research in Social and Administrative Pharmacy, 11(6), 725-748. https://doi.org/10.1016/j.sapharm.2014.12.008

Ayukekbong, J. A., Ntemgwa, M., \& Atabe, A. N. (2017). The threat of antimicrobial resistance in developing countries: Causes and control strategies. Antimicrobial Resistance and Infection Control, 6(1), 1-8. https://doi.org/10.1186/s13756-017-0208-x

Babar, Z. U. D., Scahill, S., Nagaria, R. A., \& Curley, L. E. (2018). The future of pharmacy practice research - Perspectives of academics and practitioners from Australia, NZ, United Kingdom, Canada and USA. Research in Social and Administrative Pharmacy, 14(12), 1163-1171. 
https://doi.org/10.1016/j.sapharm.2018.01.004

Badowski, M., Mazur, J. E., Lam, S. W., Miyares, M., Schulz, L., \& Michienzi, S. (2017). Engaging in collaborative research: Focus on the pharmacy practitioner. Hospital Pharmacy, 52(1), 33-43. https://doi.org/10.1310/hpj5201-33

Bartunek, J. M., \& Rynes, S. L. (2014). Academics and Practitioners Are Alike and Unlike: The Paradoxes of Academic-Practitioner Relationships. Journal of Management, 40(5), 1181-1201. https://doi.org/10.1177/0149206314529160

Bassetti, M., Giacobbe, D. R., Vena, A., \& Brink, A. (2019). Challenges and research priorities to progress the impact of antimicrobial stewardship. Drugs in Context, 8, 1-15. https://doi.org/10.7573/dic.212600

Broom, A., Broom, J., Kirby, E., Plage, S., \& Adams, J. (2015). What role do pharmacists play in mediating antibiotic use in hospitals? A qualitative study. BMJ Open, 5(11), e008326. https://doi.org/10.1136/bmjopen-2015-008326

Centers for Disease Prevention and Control. (2020). Antibiotic Resistance: A Global Threat. Antibiotic/Antimicrobial Resistance. https://www.cdc.gov/drugresistance/solutionsinitiative/stories/ar-global-threat.html

De Pelecijn, L., \& Feys, Y. (2021). Stepping out of the Comfort Zone? Challenges, Advantages and Good Practices When Conducting Academic-Practitioner Research. Journal of Policy Practice and Research, 2(3), 178-193. https://doi.org/10.1007/s42972-021-00029-y

Drăghicescu, L. M., Petrescu, A.-M., Cristea, G. C., Gorghiu, L. M., \& Gorghiu, G. (2014). Application of Problem-based Learning Strategy in Science Lessons - Examples of Good Practice. Procedia - Social and Behavioral Sciences, 149, 297-301. https://doi.org/10.1016/j.sbspro.2014.08.245

Goedhart, N. S., Blignaut-van Westrhenen, N., Moser, C., \& Zweekhorst, M. B. M. (2019). The flipped classroom: supporting a diverse group of students in their learning. Learning Environments Research, 22(2), 297-310. https://doi.org/10.1007/s10984-019-09281-2

Harbarth, S., Balkhy, H. H., Goossens, H., Jarlier, V., Kluytmans, J., Laxminarayan, R., Saam, M., Van Belkum, A., \& Pittet, D. (2015). Antimicrobial resistance: One world, one fight! Antimicrobial Resistance and Infection Control, 4(1), 1-15. https://doi.org/10.1186/s13756-015-0091-2

Kementerian Kesehatan RI. (2020). Panduan Penatagunaan Antimikroba di Rumah Sakit Edisi 2020 (2020th ed.).

Peraturan Menteri Koordinator Bidang Pembangunan Manusia dan Kebudayaan Republik Indonesia Nomor 7 Tahun 2021 tentang Rencana Aksi Nasional Pengendalian Resistensi Antimikroba Tahun 2020-2024, (2021).

Mahoney, A. R., Safaee, M. M., Wuest, W. M., \& Furst, A. L. (2021). The silent pandemic: Emergent antibiotic resistances following the global response to SARS-CoV-2. IScience, 24(4), 102304. https://doi.org/10.1016/j.isci.2021.102304

McCabe, A., Osegowitsch, T., Parker, R., \& Cox, S. (2021). Knowledge co-production in academicpractitioner research collaboration: An expanded perspective on power. Management Learning. https://doi.org/10.1177/1350507620988431

Morris, C. T., Hatton, R. C., \& Kimberlin, C. L. (2011). Factors associated with the publication of scholarly articles by pharmacists. American Journal of Health-System Pharmacy, 68(17), 16401645. https://doi.org/10.2146/AJHP100660

O.Nyumba, T., Wilson, K., Derrick, C. J., \& Mukherjee, N. (2018). The use of focus group discussion methodology: Insights from two decades of application in conservation. Methods in Ecology and Evolution, 9(1), 20-32. https://doi.org/10.1111/2041-210X.12860

Prahati, Zuhdi, S., \& Aguswan. (2017). Penyuluhan Penyusunan Rencana Pembangunan Desa di Desa Kuapan Kecamatan Tambang Kabupaten Kampar. Dinamisia, 1(1), 94-99.

Reynolds, J. L., \& Rupp, M. T. (2017). Improving clinical decision support in pharmacy: Toward the perfect DUR alert. Journal of Managed Care and Specialty Pharmacy, 23(1), 38-43. https://doi.org/10.18553/jmcp.2017.23.1.38

Sakeena, M. H. F., Bennett, A. A., \& McLachlan, A. J. (2018). Enhancing pharmacists' role in developing countries to overcome the challenge of antimicrobial resistance: A narrative review. Antimicrobial Resistance and Infection Control, 7(1). https://doi.org/10.1186/s13756018-0351-z 
Sweileh, W. M. (2021). Global research publications on irrational use of antimicrobials: call for more research to contain antimicrobial resistance. Globalization and Health, 17(1), 1-12. https://doi.org/10.1186/s12992-021-00754-9

Van Katwyk, S. R., Hoffman, S. J., Mendelson, M., Taljaard, M., \& Grimshaw, J. M. (2020). Strengthening the science of addressing antimicrobial resistance: A framework for planning, conducting and disseminating antimicrobial resistance intervention research. Health Research Policy and Systems, 18(1), 1-13. https://doi.org/10.1186/s12961-020-00549-1

World Health Organization. (2019). Antimicrobial stewardship programmes in health-care facilities in low- and middle-income countries. In A Practical Toolkit. World Health Organization.

Xie, X., Siau, K., \& Nah, F. F. H. (2020). COVID-19 pandemic-online education in the new normal and the next normal. Journal of Information Technology Case and Application Research, 22(3), 175-187. https://doi.org/10.1080/15228053.2020.1824884

Yam, E. L. Y., Hsu, L. Y., Yap, E. P. H., Yeo, T. W., Lee, V., Schlundt, J., Lwin, M. O., Limmathurotsakul, D., Jit, M., Dedon, P., Turner, P., \& Wilder-Smith, A. (2019). Antimicrobial Resistance in the Asia Pacific region: A meeting report. Antimicrobial Resistance and Infection Control, 8(1), 1-12. https://doi.org/10.1186/s13756-019-0654-8

Zhang, A., Hobman, E. V., De Barro, P., Young, A., Carter, D. J., \& Byrne, M. (2021). Self-medication with antibiotics for protection against COVID-19: The role of psychological distress, knowledge of, and experiences with antibiotics. Antibiotics, 10(3), 1-14. https://doi.org/10.3390/antibiotics10030232 